\title{
Acil servise boğulma nedeniyle başvuran hastaların geriye dönük incelenmesi
}

\author{
A retrospective evaluation of patients admitted emergency department due to drowning \\ Nurşah Başol*a, Ahmet Baydın', Türker Yardan ${ }^{b}$ \\ ${ }^{a}$ Gaziosmanpaşa Üniversitesi, Tıp Fakültesi Acil Tıp Anabilim Dalı, Tokat, Türkiye \\ ${ }^{b}$ Ondokuz Mayıs Üniversitesi, Tıp Fakültesi Acil Tıp Anabilim Dalı, Samsun, Türkiye
}

MAKALE BÍLGILERI
$\begin{array}{ll}\text { Makale geçmişi } \\ \text { Geliş tarihi } & : 21 / 12 / 2011 \\ \text { Kabul tarihi } & : 26 / 12 / 2011\end{array}$

\section{* Yazışma Adresi:}

Nurşah Başol

Gaziosmanpaşa Üniversitesi Tıp Fakültesi,

Acil Tip Anabilim Dalı,

Tokat, Türkiye

e-posta:drnursahbs@hotmail.com

\section{Anahtar Kelimeler:}

Suda boğulma

Szpilman'ın klinik sınıflandırma sistemi

Glaskow koma skoru

Prognoz

Acil servis

Mortalite

\section{Keywords:}

Drowning

Szpilman's clinical classification system

Glaskow coma score

Prognosis

Emergency service

Mortality

\section{ÖZET}

Bu çalıșmanın amacı acil servisimize suda boğulma nedeniyle başvuran hastaların epidemiyolojik açıdan değerlendirilmesidir. Suda boğulma sonucu acil servisimize başvuran erişkin hastaların (yaş $\geq 18$ ) dosya kayıtları geriye dönük olarak incelendi. Elde edilen veriler Szpilman'ın klinik sınıflamasına göre değerlendirildi. Bu çalışmaya toplam 67 hasta dahil edildi. Boğulma en fazla 18-25 yaş grubunda ve yaz aylarında görüldü. Boğulmaların çoğu denizde (\% 91) olmuştu ve hastaların çoğu kazaen (\% 92,5) boğulmuştu. Başvuru anında Glasgow Koma Skoru (GKS) 3-8 arasında olan hastalarda mortalite daha yüksekti. Szpilman'ın klinik sınıflandırma sistemine göre değerlendirildiğinde; GKS, serum sodyum düzeyi ve kan $\mathrm{pH}$ değerlerinde, grade'ler arasında istatistiksel olarak anlamlı bir farklılık mevcuttu $(\mathrm{p}<0,05)$. Hastaların acil servise geliş anında değerlendirilen GKS'u ve pupiller 1şık refleksi mortaliteyi belirlemede acil hekimine yol gösterici olabilir.

J. Exp. Clin. Med., 2012; 29:121-125

\section{ABSTRACT}

The aim of this study was to evaluate the epidemiologic features of patients who admitted to emergency department (ED) due to drowning. This study was designed retrospectively by examining medical records of the patients (age $\geq 18$ ) who were admitted to our ED after drowning. The data were evaluated according to clinical classification of Szpilman. A total of 67 patients were included in this study. The drowning was determined mostly in the 18-25 age groups and in summers. The drowning was occurred mostly in sea (91\%) and most of the patient (\% 92.5) has drowned accidentally. Those drowning patients presenting with a Glasgow Coma Score (GCS) of 3-8 on admission, mortality was higher than others. According to the degree of clinical classification of Szpilman; GCS, serum sodium and blood $\mathrm{pH}$ levels were statistically different between the Grades $(\mathrm{p}<0.05)$. The papillary light reflex and GCS which was determined on admission may be useful for emergency physician in predicting mortality.

J. Exp. Clin. Med., 2012; 29:121-125

(C) 2012 OMU

\section{Giriș}

Boğulma, sıvı ortamda batma "submersiyon" veya dalma "immersiyon" sonucu görülen ve solunum yetmezliği ile sonuçlanan bir süreçtir. Bu sürecin sonunda kurban ölebildiği gibi sağ da kalabilmektedir (Abraham, 2011). Dünyanın her yerinde ağırlıklı olarak genç erkek popülasyonunu daha yakından ilgilendiren boğulma, tüm yaş grubunda kaza sonucu meydana gelen ölümlerin üçüncü sırasını oluştururken, 5-44 yaş grubunda ise kaza sonucu ölümlerin ikinci sırasını oluşturmaktadır (Abraham, 2011). Dünyada her y1l 2000000 boğulma olayı görülmekte ve bunlardan 150000'i ölümle sonuçlanmaktadır (Layon ve Modell, 2009). Suda boğulma çoğunlukla önlenebilecek bir kaza olduğundan, halkın bu konuda bilinçlendirilmesi ile bu kazaların azaltılabileceği bir gerçektir.

Suda boğulmalar deniz, göl, nehir, yüzme havuzu, banyo küveti başta olmak üzere, su birikintisinin bulunduğu herhangi bir yerde meydana gelebilir. Su birikintilerinde, yüzme havuzlarında ve kanallarda görülen boğulma olguları genellikle çocukluk yaş grubunu ilgilendirmektedir. Amerika Birleşik Devletlerin'de çocukluk yaş grubunda boğulmaya bağlı ölümlerin \% 53'nün yüzme havuzunda gerçekleştiği 
bildirilmiștir (Branche, 1998).

Genç yaş grubundakiler çoğunlukla su ile ilişkili eğlence ve sportif faaliyetlerde, erişkinler ise genellikle profesyonel işleri sırasında boğulma ile karşı karşıya kalmaktadırlar. Banyo ölümleri ise sıklıkla ya çok yaşlılarda ya da bebeklerde görülmektedir (Elliott ve Bennett, 2003).

\begin{tabular}{cl}
\hline Tablo 1. Boğulma & $\begin{array}{l}\text { olgularında Szpilman'a göre klinik } \\
\text { Sinıflandırma sistemi }\end{array}$ \\
\hline Klasifikasyon & \multicolumn{1}{c}{ Kurtarılmış kişiler } \\
\hline Grade 0 & $\begin{array}{l}\text { Öksürük yok, solunum güçlüğü yok, } \\
\text { normal pulmoner oskültasyon. Olay yerinde } \\
\text { değerlendirme sonrasında herhangi bir } \\
\text { medikal yardıma ihtiyaçları yoktur. }\end{array}$ \\
Grade 1 & $\begin{array}{l}\text { Normal pulmoner oskültasyon; öksürük ile } \\
\text { Anormal pulmoner oskültasyon, bazı } \\
\text { alanlarda ral ile } \\
\text { Akut pulmoner ödem, arteriyel hipotansiyon } \\
\text { Grade } 3\end{array}$ \\
Grade 4 & $\begin{array}{l}\text { Akut pulmoner ödem ile birlikte arteriyel } \\
\text { hipotansiyon } \\
\text { İzole solunum arresti }\end{array}$ \\
Grade 5 & Kardiyopulmoner arrest \\
\hline
\end{tabular}

$\mathrm{Bu}$ çalışmada boğulma nedeniyle acil servisimize başvuran 18 yaş ve üzerindeki erişkin olguların; demografik özelliklerinin, boğulma yerlerinin, klinik ve laboratuar bulgularının, tedavilerinin ve mortalite oranının incelenmesi ve ülkemizdeki literatüre katkıda bulunulması amaçlanmıştır.

\section{Gereç ve yöntem}

Etik kurul izni alınmış olan (31.05.2006/230) bu geriye dönük çalışmamız, 1 Ocak 2005 ile 1 Ocak 2011 tarihleri arasında Ondokuz Mayıs Üniversitesi Tıp Fakültesi Hastanesi Acil Servisine suda boğulma nedeniyle başvuran 18 yaş ve üzerindeki 67 olguyu kapsamaktadır. Veriler hastaların dosyalarındaki kayıtlardan elde edilmiştir. Hastalarla ilgili veriler, özel olarak hazırlanmış formlara dolduruldu. Çalışma formumuz belirtilen şu değişkenleri içermekteydi; olguların demografik özellikleri (yaşı, cinsiyeti), boğulmanın nerede meydana geldiği, boğulma sonrası acil servise başvuru için geçen süre, acil servise başvuru anındaki yaşamsal bulguları, akciğer oskültasyon bulguları, Glaskow Koma Skoru (GKS), tam kan sayımı, biyokimyasal testler (sodyum, potasyum, kalsiyum, kreatinin), arteryal kan gazı, acil servise başvurduğu ay, hastanede kalma süresi ve son durumu (şifa, ölüm, bitkisel hayat). Olgular yaşlarına göre 16-25 yaş; 26-35 yaş; 36-45 yaş; 46-55 yaş; 56 yaş ve üzeri diye beş alt gruba ayrıldı.

Olgular acil servisteki nörolojik muayeneleri sonucu aldıkları Glasgow Koma Skoru (GKS)'na göre de üç alt guruba ayrıldı. GKS: 3-8 olanlar (Grup I), GKS: 9-13 olanlar (Grup II) ve GKS: 14-15 olanlar (Grup III) olarak ayrıldı. Olgular Szpilman'ın klinik sınıflandırmasına göre sınıflandırıldı (Tablo 1). Bu sınıflama ile hastalarda mortalite, GKS ve laboratuvar sonuçlarının ilişkisi incelendi.

Hastaların dosyalarından elde edilen veriler SPSS 15.0 (Statistical Package for Social Science) bilgisayar programına yüklendi ve analiz edildi. Verilerin normal dağılıma uygunluğu Kolmogorov-Smirnov testi ile değerlendirildi.
Normal dağılıma uyan veriler ortalama \pm standart sapma, uymayan veriler ise ortanca (minimum-maximum) olarak sunuldu. Gruplar arası karşılaştırmalarda Mann-Whitney U, Kruskal Wallis Varyans Analizi, Bonferroni düzeltmeli Mann-Whitney U, Ki Kare Testi ve Fisher'1n kesin testleri kullanıldı. Anlamlılık düzeyi Bonferroni düzeltmeli MannWhitney $U$ testinde $p<0,01$ ve diğer testlerde $p<0,05$ olarak kabul edildi.

\section{Bulgular}

1 Ocak 2005-1 Ocak 2011 tarihleri arasında Ondokuz Mayıs Üniversitesi Tıp Fakültesi Hastanesi Acil Servisine boğulma nedeniyle 67 hasta başvurmuştu. $\mathrm{Bu}$ hastaların 40'1 erkek (\% 59,7), 27'si (\% 40,3) kadın olup erkek/kadın oranı 1,48 idi. Olgularının yaşları 18-65 arasında değişmekte

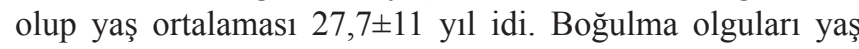
gruplarına göre incelendiğinde en fazla boğulmanın $18-25$ yaş grubunda görüldüğü ve bunu 26-35 yaş grubunun izlediğini saptand1 (Şek. 1).

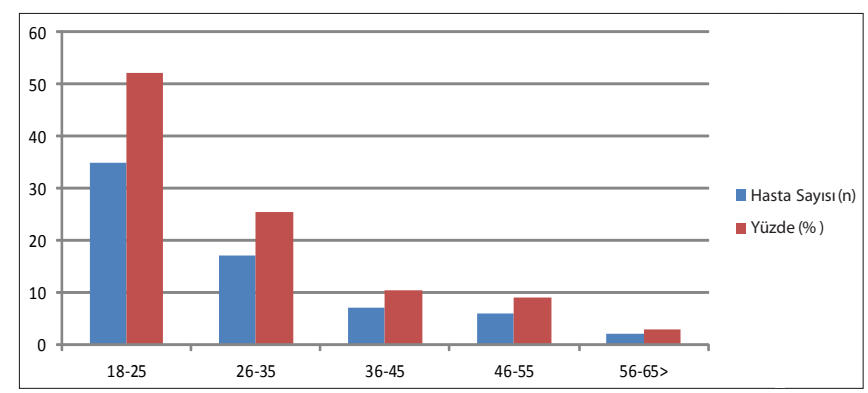

Şek. 1. Yaş gruplarına göre olguların dağılımı

Boğulma olayınınmeydanageldiğiyerleriincelediğimizde 61 olgunun (\% 91) denizde, 5 olgunun $(\% 7,5)$ derede ve 1 olgunun $(\% 1,5)$ ise havuzda boğulduğunu saptadık. Yani boğulma olgularının 61 tanesi tuzlu suda gerçekleşmişken, 6 tanesi tatlı suda meydana gelmişti. Olguların büyük çoğunluğunda (\% 92,5) kaza sonucu suda boğulma mevcut iken 5 olgu $(\% 7,5)$ özkıyım amacı ile boğulmuştu. Predispozan faktörlere baktığımızda olguların 4'ünde tekne kazası (\% 6) sonucu suya düşme ve 4'ünde (\% 6) dalma, 2'sinde alkol kullanımı (\% 3), 1'inde nöbet geçirme' nin (\% 1,5) mevcut olduğunu saptadık.

Olguların başvurdukları ayları incelendiğimizde en fazla boğulmanın 59 vaka (\% 88) ile yaz aylarında (HaziranTemmuz-Ağustos) olduğunu saptadık (Şek. 2). Olgular GKS'una göre değerlendirildiğinde, 14 olgunun (\% 20,9) GKS'u 3-8 arasinda, 7 olgunun $(\% 10,4)$ 9-13 arasinda ve 46 olgunun $(\% 68,7)$ ise 14 ve üzerinde idi.

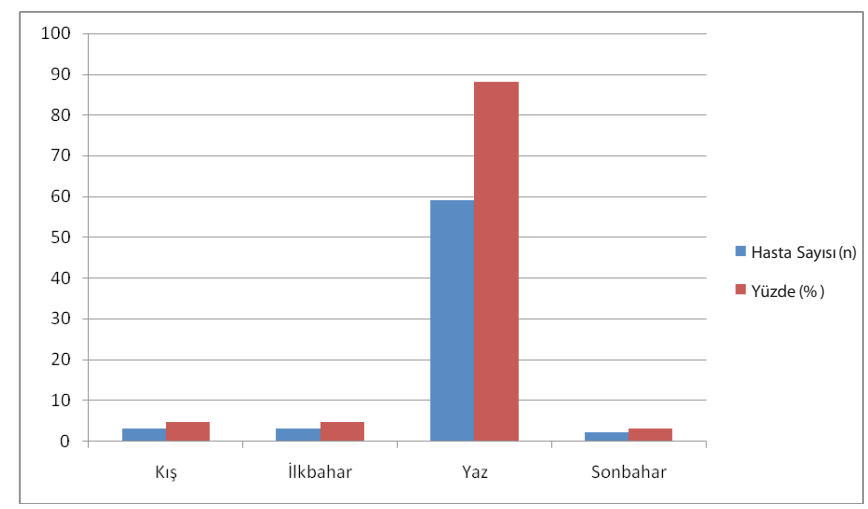

Şek. 2. Boğulmaların mevsimlere göre dağılımı 
GKS'e 3-8 arasında olan 14 olgudan 11'i (\% 78,6), GKS'u 9-13 arasında olan 7 olgudan biri (\% 14,3) ölürken, GKS'u 14 ve üzerinde olan 46 olgudan hiçbirinde mortalite görülmedi. Hastaların geliş fizik muayenesinde pupilla 1şık refleksi alınabilen 58 vakanın üçü $(\% 5,2)$ ölürken; 1şık refleksi alınamayan 9 vakanın tamamı (\% 100) ölmüştü. Hastaneye başvuru sırasındaki pupiller ışık refleksinin yanıtsız olması ile mortalite arasında istatistiksel olarak anlamlı bir ilişkinin bulunduğunu saptadık $(p<005)$. Hastaların acil servise başvurduğu anda yapılan tam kan sayımı, biyokimyasal incelemeleri ve kan gazı sonuçları ölen ve yaşayan olgularda karşılaştırıldığında sodyum, kreatin, $\mathrm{pH}, \mathrm{PCO}_{2}$ ve $\mathrm{O}_{2}$ saturasyonu açısından istatistiksel olarak anlamlı bir fark vard $1(p<0,05)$ (Tablo 2). Hastaları Szpilman'ın klinik sınıflandırma sistemine göre sınıflandırılıp mortalite ile ilişkisini incelediğimizde ölen 12 hastanın 10 tanesi (\% 83,3) Grade 6 iken, 2 tanesi Grade 5 (\% $16,7)$ idi. Diğer Grade'lerde ölüm gözlenmezken, Grade 6'da mortalite oran $1 \% 100$; Grade 5 'te ise mortalite oran $1 \% 40$ idi (Tablo 3).

\begin{tabular}{lccc}
\hline Tablo 2. Boğulma sonrası ölen ve yaşayan hastaların ortalama \\
laboratuvar sonuçları & Yaşayan & $\begin{array}{c}\mathbf{P} \\
\text { değeri }\end{array}$ \\
& Ölen & $14,1 \pm 2,1$ & $\mathrm{p}>0,05$ \\
\hline Hemoglobin (g/dL) & $14,1 \pm 2,1$ & $12315 \pm 4926$ & $\mathrm{p}>0,05$ \\
Beyaz küre (uL) & $14050 \pm 4843$ & $138,7 \pm 3,5$ & $\mathrm{p}<0,05$ \\
Sodyum (mEq/L) & $145,7 \pm 6,2$ & $0,9 \pm 0,2$ & $\mathrm{p}<0,05$ \\
Kreatin (mg/dL) & $1,3 \pm 0,4$ & $9,1 \pm 0,8$ & $\mathrm{p}>0,05$ \\
Kalsiyum (mg/dL) & $9,7 \pm 1,1$ & $3,9 \pm 0,6$ & $\mathrm{p}>0,05$ \\
Potasyum (mEq/L) & $4,2 \pm 0,4$ & $7,3 \pm 0,2$ & $\mathrm{p}<0,05$ \\
$\mathbf{p H}$ & $6,9 \pm 0,4$ & $94,9 \pm 48,8$ & $\mathrm{p}>0,05$ \\
PO $_{\mathbf{2}}$ (mmHg) & $96,8 \pm 48,8$ & $34,9 \pm 7,9$ & $\mathrm{p}<0,05$ \\
PCO $_{\mathbf{2}}(\mathbf{m m H g})$ & $76,6 \pm 37,5$ & $17,1 \pm 5,5$ & $\mathrm{p}>0,05$ \\
$\mathbf{H C O}_{\mathbf{3}}(\mathbf{m m o l} / \mathbf{L})$ & $13,8 \pm 6,3$ & $90,3 \pm 9,1$ & $\mathrm{p}<0,05$ \\
Sat $_{\mathbf{2}} \mathbf{( \% )}$ & $78,8 \pm 13,8$ & &
\end{tabular}

Tablo 3. Szpilman'ın klinik sınıflandırmasına göre olgularımızın mortalite oranlar1

\begin{tabular}{|c|c|c|c|}
\hline Grade & $\begin{array}{c}\text { Hasta } \\
\text { Sayısı } \\
\mathrm{n}(\%)\end{array}$ & $\begin{array}{c}\text { Mortalite } \\
n(\%) \\
\end{array}$ & $\begin{array}{c}\text { Szpilman'ın } \\
\text { mortalite } \\
\text { yüzdesi }(\%)\end{array}$ \\
\hline Grade 0 & $12(17,9)$ & $0 \quad(0)$ & 0 \\
\hline Grade 1 & $6(9)$ & $0 \quad(0)$ & 0 \\
\hline Grade 2 & $25(37,3)$ & $0 \quad(0)$ & 0,6 \\
\hline Grade 3 & $7(10,4)$ & $0 \quad(0)$ & 5,2 \\
\hline Grade 4 & $2(3)$ & $0 \quad(0)$ & 19,4 \\
\hline Grade 5 & $5(17,5)$ & $2(40)$ & 44 \\
\hline Grade 6 & $10(14,9)$ & $10(100)$ & 93 \\
\hline
\end{tabular}

Szpilman'ın klinik sınıflandırma sistemine göre olguların laboratuvar değerleri ve GKS incelendiğinde GKS, sodyum ve kan gazı pH değerlerinde Grade'ler arasında istatistiksel olarak anlamlı bir farklılık saptand.

Sodyum $\left[\mathrm{K}-\mathrm{W} \mathrm{x} \mathrm{x}^{2}=14,8, \mathrm{sd}=6, \mathrm{p}<0,05\right]$

$\mathrm{pH} \quad\left[\mathrm{K}-\mathrm{W} \mathrm{x} \mathrm{x}^{2}=15,7, \mathrm{sd}=6, \mathrm{p}<0,05\right]$

GKS $\quad\left[\mathrm{K}-\mathrm{W} \mathrm{x} \mathrm{x}^{2}=47,1, \mathrm{sd}=6, \mathrm{p}<0,05\right]$
Grade'ler ikişerli olarak kıyaslandığında; Grade 0 ile Grade 6 arasında GKS ve sodyum değerinde, Grade 1 ile Grade 6 arasında GKS ve pH değerinde, Grade 0 ile Grade 5 arasında, Grade 2 ile Grade 3 arasında, Grade 2 ile Grade 5 arasında ve Grade 2 ile Grade 6 arasında GKS'sinde anlaml bir fark vard1 (Tablo 4).

Ölen 12 olgunun (\% 18) 6 tanesi acil servise getirildiğinde kardiyopulmoner arrestte olup yapılan kardiyopulmoner resüsitasyona cevap vermemişti. Diğer 6 olgudan 3 tanesi hipoksik iskemik ensefalopatiden, 2 tanesi sepsisten ve 1 tanesi de spinal travma sonucu solunum arrestinden kaybedilmişti.

\section{Tartıșma}

Suda boğulmalar tüm dünyada ağırlıklı olarak genç erkekleri daha yakından ilgilendirmektedir. Erkeklerde boğulma riskinin yüksek olmasının başlıca nedenleri; erkeklerin kadınlara göre daha fazla suda riskli davranışlar göstermeleri, suya girme sıklıklarının fazlalığı, tek başına yüzme ve alkollü bir şekilde yüzme olarak bildirilmiştir (Murray ve Lopez, 1997). Lakadamyalı ve ark. (2008) boğulma olgularının demografik özelliklerini inceledikleri geriye dönük çalışmalarında erkek cinsiyette boğulma sayısının kadın cinsiyete göre oldukça fazla olduğunu rapor etmişlerdir. Söyüncü ve ark. (2008) ülkemizde yaptıkları bir başka çalışmada boğulma olayının \% 67,6 oranı ile erkeklerde fazla görüldüğünü bildirmişlerdir. Yurt dişında 2304 olgu üzerinde gerçekleştirilen bir çalışmada boğulma olayının \% 74,2 oranında erkek cinsiyette görüldüğü rapor edilmiştir (Szpilman, 1997). Ellis ve ark. (1995) erkeklerin kadınlara oranla 1,7 kat daha fazla bir oranda boğulmaya maruz kaldıklarını gözlemlemişlerdir. Bizim çalışmamız da literatürle uyumlu idi, erkek cinsiyetin kadin cinsiyete oranla 1,5 kat daha fazla boğulmaya maruz kaldığını saptadık.

Tablo 4. Szpilman'ın klinik sınıflandırmasına göre olguların ortalama $\mathrm{pH}$, Sodyum ve GKS değerleri

\begin{tabular}{|c|c|c|c|}
\hline Grade & pH & Sodyum & GKS \\
\hline Grade 0 & $7,35 \pm 0,14$ & $137,3 \pm 3^{\mathbf{b}}$ & $14,3 \pm 1,5^{\mathbf{b}, \mathbf{c}}$ \\
\hline Grade 1 & $7,36 \pm 0,4^{a}$ & $136,8 \pm 2,5$ & $15 \pm 0^{\mathrm{a}}$ \\
\hline Grade 2 & $7,26 \pm 0,2$ & $138,9 \pm 3,5$ & $14,7 \pm 1,2^{\mathrm{d}, \mathrm{e}, \mathrm{f}}$ \\
\hline Grade 3 & $7,26 \pm 0,1$ & $140,9 \pm 3,2$ & $11,7 \pm 4,5^{\mathrm{d}}$ \\
\hline Grade 4 & $7,20 \pm 0,2$ & $142,5 \pm 5$ & $15 \pm 0$ \\
\hline Grade 5 & $7,18 \pm 0,3$ & $139,4 \pm 3,7$ & $7,6 \pm 4,3^{\mathrm{c}, \mathrm{e}}$ \\
\hline Grade 6 & $6,67 \pm 0,1^{\mathrm{a}}$ & $147,8 \pm 6,2^{\mathrm{b}}$ & $3 \pm 0^{\mathbf{a}, \mathbf{b}, \mathbf{f}}$ \\
\hline \multicolumn{2}{|c|}{$\begin{array}{l}\mathrm{a}: \mathrm{p}<0.01 \text { Grade } 1 \text { ile } 6 \text { için } \\
\mathrm{b}: \mathrm{p}<0.01 \text { Grade } 0 \text { ile } 6 \text { için } \\
\mathrm{c}: \mathrm{p}<0.01 \text { Grade } 0 \text { ile } 5 \text { için }\end{array}$} & \multicolumn{2}{|c|}{$\begin{array}{l}\mathrm{d}: \mathrm{p}<0.01 \text { Grade } 2 \text { ile } 3 \text { için } \\
\mathrm{e}: \mathrm{p}<0.01 \text { Grade } 2 \text { ile } 5 \text { için } \\
\text { f: } p<0.01 \text { Grade } 2 \text { ile } 6 \text { için }\end{array}$} \\
\hline
\end{tabular}

Söyüncü ve ark. (2008) çalışmalarında tüm yaş gruplarında boğulmaların pik yaptığı 3 dönemin bulunduğunu ve bu dönemlerin 0-5 yaş, 15-25 yaş ve 40 yaş üzeri olduğunu saptamışlar ve en fazla boğulmanın \% 38'lik bir oranla 1525 yaş grubunda görüldüğünü bildirmişlerdir. Yurt dişında yapılan ve yine tüm yaş gruplarının incelendiği bir çalışmada $\%$ 28,3 oranı ile en fazla boğulmanın 20-24 yaș grubunda görüldüğü ve bunu \% 25,1 oranı ile 15-19 yaş grubunun izlediği raporlanmıştır (Anary ve ark., 2010). Biz, çalışmamızda 18 yaş ve üzerindeki boğulmaları inceledik.

Hastalarımızın yaşları 18 ile 65 yıl arasında değişmekteydi ve en fazla 18-25 yaş grubunda boğulma olayının görüldüğünü 
saptadık. Boğulmalar tüm yaş grupları dikkate alındığında kaza sonucu meydana gelen ölümlerin üçüncü sırasını oluşturmaktadır (Abraham, 2011). Kaza sonucu olan suda boğulmalar literatürde fazla oranda bildirilse de özkıyım ya da cinayet amaçlı suda boğulmalar da az bir oranda görülebilmektedir. Çalışmamızda boğulma olgularının nedeni \% 92,5 oranında kaza iken, \% 7,5 oranında ise özkıyımdı. Anary ve ark. (2010) çalışmalarında boğulmaların \% 95,5 oranında kaza sonucu görüldüğünü ve \% 3,6 oranında ise öz kıyım sonucunda görüldüğünü bildirmişlerdir. Gregorakos ve ark. (2009) ise boğulmaların tümünde nedenin kaza olduğunu ifade etmişlerdir. Ülkemizde Cantürk ve ark. (2009) tarafindan yapılmış olan bir çalışmada kaza sonucu boğulmaların \% 97,3 oranında, öz kıyım sonucu boğulmaların ise \% 2,7 oranında görüldüğü bildirilmiştir. Çalışmamızdaki özkıyım sonucu boğulmaların diğer çalışmalardakinden yüksek olmasının nedeni olarak, bölgemizin deniz kıyısında olması ve intihar etme potansiyeli bulunan insanların ilaçlara, ve insektisitlere alternatif olarak bu yolu kullanmasından kaynaklandığını düşünmekteyiz.

Boğulma olgularımızın en fazla (\% 88 oranında) yaz aylarında acil servise başvurduğunu saptadık. Ülkemizde farklı bölgelerde yapılmış bulunan çalışmalarda da boğulma olayının sıklıkla yaz aylarında meydana geldiği bildirilmiştir (Arslan ve ark., 2005; Cantürk ve ark., 2009). Yurt dışında yapılan ve pediatrik yaş grubundaki boğulma olaylarının da incelendiği geniş kapsamlı bir çalışmada boğulmaların \% 87 oranında ilkbahar ve yaz aylarında görüldügü raporlanmıştır (Somers ve ark., 2005). Çalışmamız mevsimsel faktörler açısından literatürle uyumludur.

Coğrafik özellikler mevsimsel dağılımı etkileyebileceği gibi olayın gerçekleştiği yeri de (tatlı su, tuzlu su) etkileyebilmektedir. İç Anadolu bölgesinde Cantürk ve ark. (2009) tarafından yapılmış çalışmada boğulmaların \% 86,5 oranında tatlı suda gerçekleştiği bildirilmişken, Akdeniz bölgesinde Lakadamyalı ve ark. (2008) tarafindan gerçekleştirilen çalışmada boğulmaların \% 65,6 oranı ile tuzlu suda görüldüğü rapor edilmiştir. Biz çalışmamızda boğulmaların \% 91 oranıyla tuzlu suda gerçekleştiğini saptadık. Bölgeler arasındaki bu farklılıklar coğrafi özelliklerin suda boğulmalara olan etkisini göstermektedir.

Elliott ve Bennett (2003) yapmış oldukları çalışmada epilepsi gibi bilinç kaybına neden olabilen hastalıkların, ilaç kullanımının, alkol kullanımının, deniz ulaşımı kazalarının, endüstriyel balıkçılığın, su sporlarının, dalış kazalarının ve çocuklar üzerindeki ebeveyn gözetiminin yetersizliği gibi etkenlerin boğulma için predispozan faktörler olduğunu raporlamışlardır. Alkolün boğulma olgularında predispozan faktör olduğu yapılan farklı çalışmalarda sırasıyla \% 34,3, $\%$ 5,9, \% 2,3 olarak bildirilmiştir (Lakadamyalı ve ark., 2008; Söyüncü ve ark., 2008; Gregorakos ve ark., 2009). Gregorakos ve ark. (2009) aynı zamanda olguların \% 2,3'nün nöbet geçirme sonrasında boğulduklarını ifade etmişlerdir. Boğulma için bir diğer predispozan faktör ise tekne kazalarıdır. Lakadamyalı ve ark. (2008) tekne kazası sonucu boğulma oranını \% 9,3 bildirmiş iken, Anary ve ark. (2010) bu oranın \% 1,1 olduğunu bildirmişlerdir. Biz olgularımızın \% 3'ünde predispozan faktör olarak alkollü bir şekilde suya girme, \% 3'ünde tekne kazası ve \% 1,5'inde ise epileptik nöbet geçirmenin olduğunu saptadık. İnsanların alkollü bir şekilde suya girmemeleri, ilaç kullanan veya hastalığı bulunanların yalnız başına yüzmemeleri ya da yüzerken can yeleği ile yüzmeleri gibi bir takım koruyucu önlemlerin alınması ile boğulma olgularının sayısının azaltılabileceğini düşünmekteyiz.

Hastaların acil servise geliş anında bakılan GKS'si ve pupillerin 1şığa cevabı hastaların nörolojik durumlarını değerlendirmede en önemli belirteçlerdir. Lavelle ve Shaw (1993) geriye dönük olarak 44 boğulma olgusunu incelemişler ve kötü nörolojik prognozun en iyi göstergesi olarak GKS'nin 5'in altında olması ile birlikte pupillerin 1şığa cevapsızlığı olduğunu ifade etmişlerdir. Başka bir çalışmada başarılı bir kardiyopulmoner resüsitasyon sonrası yoğun bakım ünitesinde takip edilen 43 olguda GKS'nin 5 ve altında olması ile pupillerin 1şığa cevapsızlığının direkt mortalite ile ilişkili olduğu bulunmuştur (Ballesteros ve ark., 2009). Söyüncü ve ark. (2008) hastaneye başvuru sırasında GKS'si 14'ün üzerinde olanlarda prognozun iyi olduğunu ve ölümün görülmediğini buna karşıllı GKS'si 4 ve altında olanlarda prognozun kötü olduğunu bildirmişlerdir. Çalışmamızın sonucuna göre biz de düşük GKS'nin $(\mathrm{GKS}<5)$ ve pupiller cevapsızlığın kötü prognozu gösterdiğini söyleyebiliriz. Zira acil servise gelişinde pupiller 1şık refleksi alınamayan tüm olgularımız ölmüştü.

Geçmiş yıllarda laboratuvar sonuçları referans alınarak yapılan çalışmalarda, farklı osmolaritelere sahip iki ayrı su tipinin vücutta kan volümü, serum elektrolit konsantrasyonları ve kardiyovasküler fonksiyon açısından önemli değişikliklere neden olduğu ifade edilirken, günümüzde artık bu iki ayrı su tipinin klinikte anlamlı değişikliklere neden olmadığı ve klinik tabloyu belirleyen esas faktörün hipokside kalma süresi olduğu belirtilmektedir. Biz bu nedenledir ki tatlı ve tuzlu suda boğulanların serum elektrolit değerlerini karşılaştırmadık. Gregorakos ve ark. (2009) boğulma olayı sonrası yaşayan ve ölen olgular arasında sodyum değerleri açısından anlamlı bir farkın bulunmadığını bildirmişlerdir. Hasan ve ark.(1971) olguların \% 25'inde hafif hipernatremi bulunurken \% 60'ında hipokalemi bulunduğunu ve bu elektrolit değişikliklerinin klinik olarak önemsiz olduğunu rapor etmişlerdir. Oehmichen ve ark. (2008) boğulma sonrası ölen ve yaşayan olguları incelemişler ve ölen olguların \% 70'inde sodyum değerinin normal bulunduğunu, \% 10'unda ise yüksek bulunduğunu bildirmişlerdir. Biz, çalışmamızda ölen ve yaşayan olgular arasında sodyum değerleri açısından istatistiksel olarak anlamlı bir fark saptadık. Sodyumun dışındaki diğer elektrolitlerde bir farklılık saptamadığımızı göz önünde bulundurursak sadece sodyum değerindeki değişikliği dilüsyonla açıklamanın doğru olmayacağını söyleyebiliriz.

Boğulma sonrası hipoksiye ikincil olarak böbreklerin etkilenebileceği, akut tübüler nekrozun gelişebileceği ve buna bağlı olarak da akut böbrek yetmezliğinin görülebileceği rapor edilmiştir. Spicer ve ark. (1999) boğulma sonrasında olgularda \% 50 oranında akut böbrek hasarı görüldüğünü ve kreatin seviyesinin bu hastalarda ortalama 2,7 $\pm 3,7 \mathrm{mgr} / \mathrm{dL}$ olduğunu bildirmişlerdir. Ballesteros ve ark. (2009) ise boğulma sonrası ölen olgularda ölmeyenlere göre kreatin değerlerinin daha yüksek bulunduğunu ve bunun istatistiksel olarak anlamlı olduğunu ifade etmişlerdir. Biz, çalışmamızda ölen ve yaşayan olguların kreatin değerlerini karşılaştırdığımızda, ölen olguların ortalama kreatin değerinin yaşayan olguların ortalama kreatin değerine göre yüksek olduğunu ve bunun 
istatistiksel olarak anlam taşıdığını saptadık. Biz de ölen hastalardaki kreatin değerlerinin yüksek olmasının uzun süreli doku hipoksisi sonrasında gelișen reperfüzyon hasarından kaynaklandığını düşünmekteyiz.

Çalışmamızda olguların kan gazını incelediğimizde; $\mathrm{pH}$, oksijen saturasyonu ve parsiyel $\mathrm{CO}_{2}$ basıncı $\left(\mathrm{PCO}_{2}\right)$ açısından ölen ve yaşayan olgular arasında istatistiksel olarak anlamlı bir farkın bulunduğunu gözlemledik. Ballesteros ve ark. (2009) boğulma olgularında prognozu belirleyen faktörleri incelediklerinde arteriyel kan gazında pH'nın asidotik olduğu olguların mortal seyrettiğini gözlemlemişler. Yapılan farklı bir çalışmada ise boğulan olgulardaki klinik bulgular ve laboratuvar değerleri incelenmiş ve mortal seyreden olgularda pH'nın 6,5 ile 7,3 arasında değiştiği ve asidozun hipoksiye ikincil olarak geliştiği bildirilmiştir (Oehmichen ve ark., 2008). Boğulan olgularda reoksijenizasyon ve reperfüzyon sağlandıktan sonra bile asidozun uzun süre devam etmesi nedeniyle, pH'nın parsiyel oksijen basıncına göre hipoksik hasarı ve mortaliteyi göstermede daha iyi bir belirteç olduğunu düşünmekteyiz. Zira çalışmamızda ölen olgularda belirgin bir

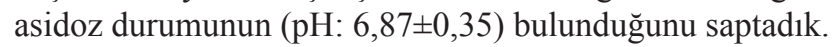

Szpilman'nın önerdiği klinik derecelendirmede mortalite oranı \% 0-93 arasında değişmektedir (Tablo 3). Söyüncü ve ark. (2008) çalışmalarında Grade 6'daki olgularının tamamının öldüğünü ifade etmişlerdir. Biz çalışmamızda, Szpilman'ın çalışmasına benzer şekilde Grade arttıkça mortalite oranımızın da arttığını gözlemledik. Grade 5'de mortalite oranımız \% 40 iken Grade 6'da \% 100 idi. Szpilman'ın klinik sınıflandırma sistemine göre olguların laboratuvar değerleri ve GKS incelendiğinde GKS, ortalama sodyum değeri ve ortalama $\mathrm{pH}$ değerlerinde, grade'ler arasında istatistiksel olarak anlamlı farklılık vardı (Tablo 4). Bu konu üzerinde yapılmış başka bir çalışma bulunmadığından bu sonuçlarımızı literatürle kıyaslayamadık. Sonuç olarak boğulma olgularının hastaneye başvuru anındaki GKS'si ne kadar düşük, asidozu ne kadar derin ve Szpilman Grade ne kadar yüksekse prognozun da o kadar kötü olacağını ve bu hastalarda mortalitenin diğerlerine göre daha yüksek seyredeceğini söyleyebiliriz.

\section{KAYNAKLAR}

Abraham, E., 2011. Drowning. In from textbook of critical care, 6th edition. M. Fink, E. Abraham, P. Vincent, eds. Elsevier, Amsterdam, 91, $1230-1234$.

Anary, S.H., Hossein, S., Sheikhazadi, A., Ghadyani, M.H., 2010. Epidemiology of drowning in Mazandaran Province, North of Iran. Am. J. Foren. Med. Path. 3, 236-242.

Arslan, M., Kar, H., Akçan, R., Çekin, N., 2005. Suda boğulma tanısında kullanılan yöntemlerin irdelenmesi. Adli Tıp Bülteni. 1, 29-34.

Ballesteros, M., Gutirrez-Cuadra, M. Munoz, P., Minabres, E., 2009. Prognostic factors and outcome after drowning in an adult population. Acta Anaesth. Scand. 53, 935-940.

Branche, C.M., 1998. "What is really happening with drowning rates in the United States?” In from Drowning- New perspectives on intervention and prevention, J.R. Fletemeyer, S.J.Freas, eds. CRC Press, Boca Raton, 31-42.

Cantürk, N., Cantürk, G., Karbeyaz, K., Özdeş, T., Dağalp, R., Çelik., S., 2009. Evaluation of the deaths due to drowning autopsied between 2003 and 2006 in Ankara. Türkiye Klinikleri J. Med. Sci. 5, 1198-1205.

Elliott, D.H., Bennett P.B., 2003. Drowning and near-drowning. In From The Physiology and Medicine of Diving. P.Bennett, D.H. Elliott eds. Saunders Company Ltd, 181-184.

Ellis, A.A., Trent, R.B., 1995. Hospitalizations for near drowning in California: Incidence and costs. Am. J. Public Health. 8, 1115-1118.

Gregorakos, L., Markou, N., Psalida, V., Kanakaki, A., Alexopoulou, A., Sotiriou, E., Damianos, A., Myrianthefs, P., 2009. Near- drowning: Clinical course of lung injury in adults. Lung. 187, 93-97.

Hasan, S., Avery, W.G., Fabian, C., Sackner, M.A., 1971. Near drowning in humans: A report of 36 patients. Chest. 59, 191-197.

Lakadamyalı, H., Doğan, T., 2008. Türkiye'de bir turizm yöresinde suda boğulma olgularının irdelenmesi. Türkiye Klinikleri, J. Med. Sci. 28, 143-148.

Lavelle, J.M., Shaw, K.N., 1993. Near drowning: Is emergency department cardiopulmonary resuscitation or intensive care unit cerebral resuscitation indicated? Crit. Care Med. 21,368-373.

Layon, A.J., Modell, J.H., 2009. Drowning: Update. Anesthesiology, 110, 1390-1401.

Murray, C.J., Lopez A.D., 1997. Mortality by cause for eight regions of the world. In From Global Burden of Disease Study, Lancet. 349,12691276.

Oehmichen, M., Hennig, R., Meissner, C., 2008. Near-drowning and clinical laboratoy changes. J.Legal Med. 10, 1-5.

Somers, G.R., Chiasson, D.A., Smith, C.R., 2005. Pediatric drowning: A 20 year review of autopsied cases: Demografic features. J. Am. Forensic Med. Pathol. 4, 316-319.

Söyüncü, S., Işık, S., Bektaş, F., Yiğit, Ö., 2008. Acil servise suda boğulma nedeniyle başvuran hastaların prognozunun belirlenmesinde GKS ve REMS skorlarının değerliliği. TrJEM. 2, 67-72.

Spicer, T., Quinn, D., Nyi, N.N., Nankivell, B.J., Hayes, J.M., Savdie, E., 1999. Acute renal impairment after immersion and near-drowning. J. Am. Soc. Nephrol. 10, 382-386.

Szpilman, D.,1997. Near-drowning and drowning classification: A proposal to stratify mortality based on the analysis of $1,831 \mathrm{c}$. Chest. 112 , $660-665$. 